\title{
INTENTIONAL REPLANTATION OF MULTIPLE TEETH
}

Ivashchenko $A V^{1}$, Fedyaev $\mathrm{IM}^{2}$, Yablokov $\mathrm{AE}^{2} \otimes$, Kolganov $\mathrm{IN}^{2}$, Balandin $\mathrm{El}^{3}$, Tlustenko VP²

1 Innovative Dental Center, Samara

${ }^{2}$ Samara State Medical University, Samara

${ }^{3}$ Medical University Reaviz, Samara

One of the alternatives to permanent tooth removal is intentional reimplantation. A tooth saved by reimplantation can later serve as a support for various types of dental prostheses. Tooth replantation is indicated if there is an infection in the periapical area unresponsive to conservative treatment or apicoectomy is not possible, etc. The female patient S. presented with missing teeth and significant coronal decay both on the upper and lower jaws. Three months after the teeth had been extracted and reimplanted, the patient underwent another panoramic radiography scan. On the post-op orthopantomogram the dental cement appeared evenly distributed in the root canals and the trabecular bone tissue was rebuilding in the periapical area of the replanted teeth. Later, we installed fixed dental porcelain-fused-to-metal prostheses supported by the replanted teeth. The patient also received removable dentures. A 2-year follow-up showed no signs of pathologic mobility in the replanted teeth, robust trabecular tissue regeneration in the periapical area and stability of dental prostheses supported by the replanted teeth.

Keywords: tooth reimplantation, apicoectomy, tooth extraction, prosthodontics

$\checkmark$ Correspondence should be addressed: Alexey E. Yablokov

Novo-Vokzalnaya 167A, kv. 61, Samara, 443016; s1131149@yandex.ru

Received: 04.04.2018 Accepted: 10.04.2018

DOI: $10.24075 / \mathrm{brsmu} .2018 .030$

\section{МНОЖЕСТВЕННАЯ РЕПЛАНТАЦИЯ ЗУБОВ}

\author{
А. В. Иващенко ${ }^{1}$, И. М. Федяев ${ }^{2}$, А. Е. Яблоков ${ }^{2}$, И. Н. Колганов ${ }^{2}$ Е. И. Баландин ${ }^{3}$, В. П. Тлустенко \\ ' Инновационный стоматологический центр, Самара \\ ${ }^{2}$ Самарский государственный медицинский университет, Самара \\ ${ }^{3}$ Медицинский университет «Реавиз», Самара
}

\begin{abstract}
В настоящее время одной из альтернатив операции удаления зуба является реплантация. Методика позволяет сохранить зуб, подлежащий удалению, который в последующем может служить опорой для различных ортопедических конструкций. Показаниями к реплантации зуба являются: наличие очага инфекции в периапикальной области при неэффективности консервативных методов лечения, невозможность проведения резекции верхушки корня и т. д. У пациентки С., обратившейся с жалобами на частичное отсутствие зубов, были выявлены значительные разрушения коронковой части зубов верхней и нижней челюстей. После удаления с последующей реплантацией через 3 месяца была выполнена ортопантомограмма. На рентгенографии выявлено равномерное заполнение корневых каналов цементом по всей длине и состоятельная трабекулярная костная ткань в области верхушек корней реплантированных зубов. С опорой на реплантируемые зубы были установлены несъемные металлокерамические конструкции. В последующем проведено протезирование съемными ортопедическими протезами. По результатам проведенного лечения и анализа рентгенологических данных за двухлетний срок наблюдения нами было установлено отсутствие патологической подвижности у реплантированных зубов, состоятельность костной ткани в области их верхушек и стабильность ортопедических конструкций, опорой для которых послужили реплантированные зубы.
\end{abstract}

Ключевые слова: реплантация зуба, резекция верхушки корня, удаление зуба, протезирование

$\triangle$ Для корреспонденции: Яблоков Алексей Евгеньевич

ул. Ново-Вокзальная, д. 167А, кв. 61, г. Самара, 443016; s1131149@yandex.ru

Статья получена: 04.04.2018 Статья принята к печати: 10.04.2018

DOI: 10.24075/vrgmu.2018.030

Replantation is the reinsertion of an extracted tooth back into its socket. An eligible tooth will have a well-preserved crown and no widely diverging or curved roots [1-4]. The replanted tooth can be later capped with a dental crown, both porcelainfused-to-metal or any type of all metal [5-6]. Replantation has a favorable prognosis if the alveolar periosteum is intact and the periodontal ligament minimally damaged; the total loss of the ligament will result in the direct attachment of the root to the bone and therefore entails a poor prognosis. The replanted tooth can remain functional for 1 to 3 years or even longer; the best results are observed for otherwise healthy luxated or avulsed teeth [7-9].
Further improvement of the replantation technique will take management of the partial loss of teeth to a new level [10-12]. The aim of the present work was to study the aspects of bone regeneration in the periapical area of replanted teeth.

\section{Clinical case report}

The female patient S. aged 41 presented with missing teeth. The oral cavity was examined and panoramic radiography performed to reveal severe coronal decay both on the upper and lower jaws in teeth 1.1, 1.2, 1.3, 1.4, 1.6, 2.4, 2.5, 2.7, 3.2, 3.4, 3.7, 4.3, 4.4, 4.5, and 4.6 (Fig. 1). 
Based on the orthopantomogram and visual examination, a decision was made to completely remove teeth 1.2, 1.4, 1.6, $2.4,2.5,2.7,3.1,3.2,3.7,4.1,4.3$, and 4.6 and replant teeth $1.1,1.3,3.4,4.4$, and 4.5. Extractions were performed over a series of visits and were followed by immediate intentional replantation; the patient was anesthetized with $1.7 \mathrm{ml}$ of Septanest 1 : 100 000, a local dental anesthetic by Septodont, France. Teeth 1.1, 1.3, 3.4, 4.4 were extracted very gently, as we aimed to maximally preserve the periodontal tissue and the alveolar periosteum. Unfortunately, during the extraction of tooth 4.5 the distal periosteum, part of the bone tissue and the periodontal ligament were damaged. After removing the roots, we performed an extraoral apicoectomy followed by retrofilling with a dental cement. Teeth 1.1, 1.3, 3.4, 4.4, and 4.5 were replanted and the patient was offered a post and core dental restoration and further prosthodontic treatment. The patient was scheduled for a panoramic radiography scan three month after the replantation (Fig. 2), which revealed an even distribution of the dental cement in the root canals and the rebuilding trabecular bone tissue in the periapical area of the replanted teeth. So, we decided to install fixed dental porcelainfused-to-metal prostheses supported by the replanted teeth. Later the patient received removable partial dentures for the upper and lower jaws. The prostheses were reinforced with a cobalt-nickel-chromium alloy.

The patient presented for a final checkup two years later. She had no complaints; the replanted teeth were stable with no signs of pathologic mobility. Intraoral radiographic images of teeth $1.1,1.2,1.3$, and 3.4 showed robust trabecular tissue in the periapical area. No sites of inflammation were observed (Fig. 3 A, B).

\section{Case discussion}

Throughout the follow-up period the periodontal space was visible on the radiographs along the entire root length in teeth 1.1-1.3. No signs of bone tissue pathology were observed in the root area. This observation led us to conclude a fibroosseous type of integration process.

Bitewing radiography of teeth 4.4 and 4.5 (Fig. 4) revealed root demineralization in tooth 4.5 , the narrowing of the distal periodontal space and the absence of inflammation in the periapical area. When palpated, the teeth were stable with no signs of pathologic mobility. The outcome was not perfect because the extraction of tooth 4.5 had been traumatic and accompanied by a considerable damage to the periodontal ligament and the alveolar periosteum.

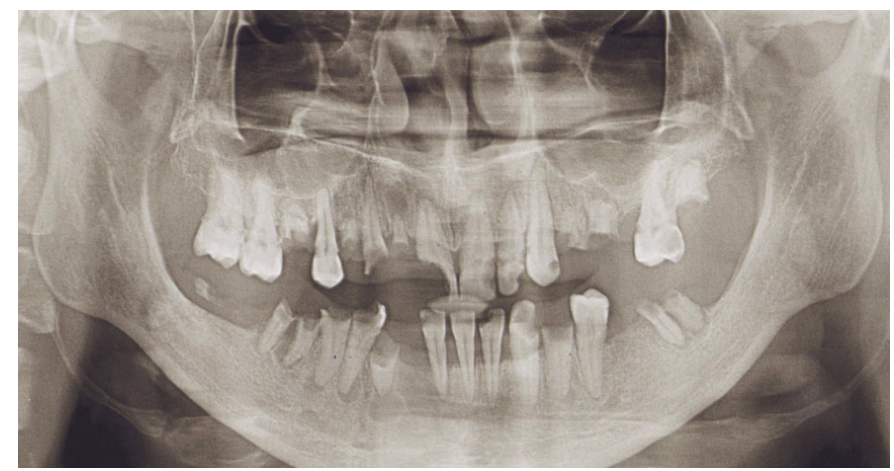

Fig. 1. The orthopantomogram of the female patient $\mathrm{S}$. aged 41 before reimplantation

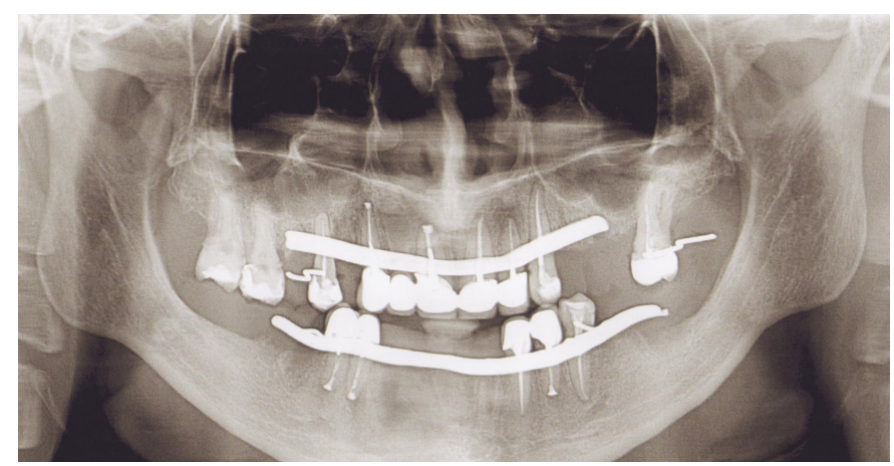

Fig. 2. The orthopantomogram of the same patient 3 months after the replantation

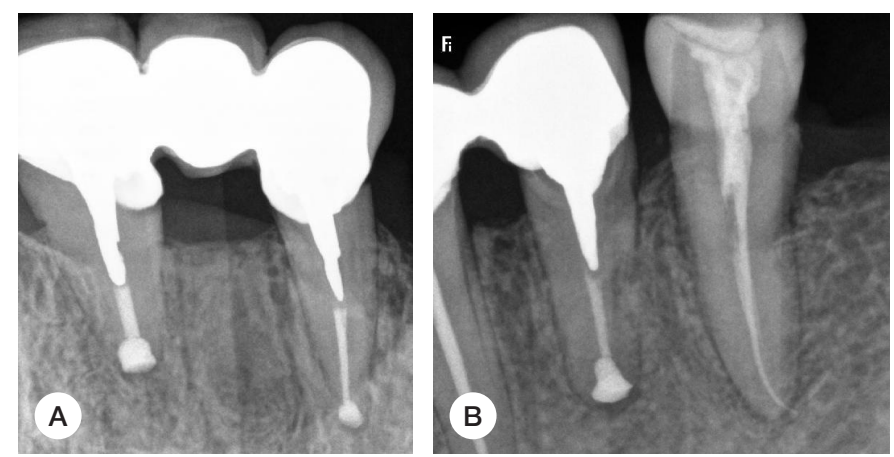

Fig. 3. (A, B). Bitewing radiographs of the replanted teeth 1.1-1.3 and 3.4 of the same patient 


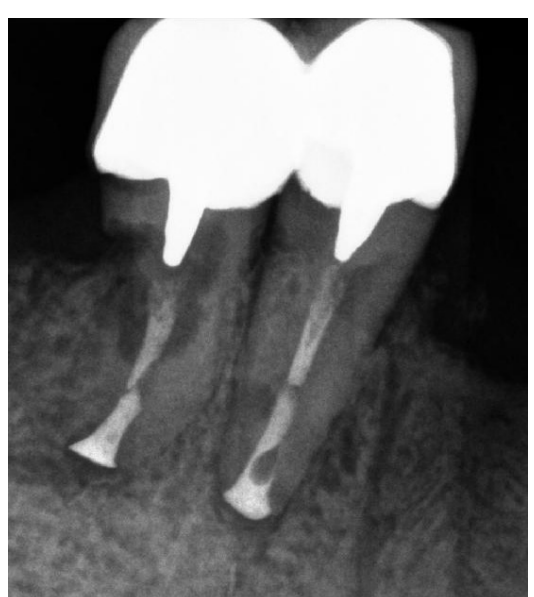

Fig. 4. The bitewing radiograph of the replanted teeth 4.4 and 4.5 of the same patient

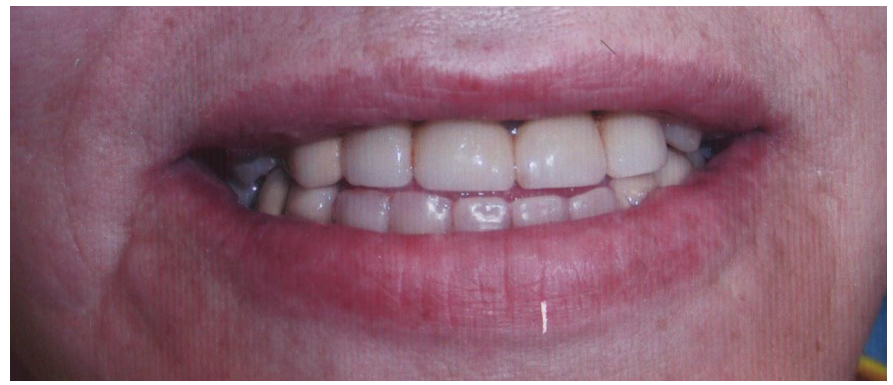

Fig. 5. The same patient with dental prostheses supported by the replanted teeth. The follow-up lasted for two years

\section{CONCLUSIONS}

Based on the physical examinations and the analysis of radiographs taken over a 2-year follow-up (Fig. 5), we established that the replanted teeth did not show any signs of pathologic mobility, the bone tissue in the periapical area was rebuilt and dental prostheses supported by the replanted teeth were stable. The effect of complications that accompanied the extraction on further replantation allows us to conclude that a successful outcome can be achieved through careful and gentle handling of the periodontal ligament and the periosteum. Thus, replantation success directly depends on two factors: the extent of the initial root decay and the damage to the periosteum and the periodontal ligament during extraction.

\section{References}

1. Andersen JO. Atlas of replantation and transplantion of teeth. Philadelphia: Saunders; 1992. p. 207.

2. Kosmagambetova A. T. Istorija razvitija operacii replantacii zuba. Problemy stomatologii. 2007; 4: 66-8.

3. Kovalenko E. V., Antonova A. A. Replantacii postojannyh zubov $u$ detej. Problemy i puti reshenija. Fundamental'nye issledovanija. 2012; 12 (1): 78-81.

4. Pantjuhin A. I. Vozmozhnosti regeneracii replantirovannogo zuba Sbornik statej I mezhdunarodnogo kongressa po problemam zubnoj transplantologii. Ufa. 1994: 35-7.

5. Ivashhenko A. V., Balandin E. I., Zubkov D. V. Rol' tkanej periodonta $\vee$ reparativnyh processah pri replantacii zubov (blizhajshie varianty). Klinicheskaja stomatologija. 2016; 4 (80): 52-4.

6. Kovan R. D. Celenapravlennaja replantacija opornogo zuba dlja uderzhanija s"emnogo chastichnogo proteza. Kvintjessencija (stomat. ezhegodnik). 1992: 95-100.

\section{Литература}

1. Andersen JO. Atlas of replantation and transplantion of teeth. Philadelphia: Saunders; 1992. p. 207.

2. Космагамбетова А. Т. История развития операции реплантации зуба. Проблемы стоматологии. 2007; 4: 66-8.

3. Коваленко Е. В., Антонова А. А. Реплантации постоянных зубов у детей. Проблемы и пути решения. Фундаментальные исследования. 2012; 12 (1): 78-81.

4. Пантюхин А. И. Возможности регенерации реплантированного 
зуба. Сборник статей I международного конгресса по проблемам зубной трансплантологии. Усра. 1994: 35-7.

5. Иващенко А. В., Баландин Е. И., Зубков Д. В. Роль тканей периодонта в репаративных процессах при реплантации зубов (ближайшие варианты). Клиническая стоматология. 2016; 4 (80): 52-4.

6. Кован Р. Д. Целенаправленная реплантация опорного зуба для удержания съемного частичного протеза. Квинтэссенция (стомат. ежегодник). 1992: 95-100.

7. Богатов А. И. Модифицированный способ реплантации зубов. Сборник статей I международного конгресса по проблемам зубной трансплантологии. Уфра. 1994: 40-2.

8. Богатов А. И. Реплантация зубов. Сборник статей $V$ съезда стоматологической ассоциации России. Москва. 1999: 226-7. 9. Секлетов Г. А. Особенности подготовки зуба к реплантации при полном вывихе зуба. Стоматология. 2008; 87 (1): 83-4.

10. Митрофанов В. И. Реплантация - за и против. Клинический случай реплантации корня, разрушенного и восстановленного культевой вкладкой, с целью сохранения мостовидной конструкции, включающей проблемный зуб, в области которого возник свищевой ход. Эндо-донтия Today. 2010; 4: 39-41.

11. Гиоева Ю. А., Матвеева М. Н. Аутогенная трансплантация зубов. Ортодонтия. 2010; 1 (49): 44-52.

12. Михайлова Е. В. Одномоментная реплантация ретинированного зуба при ортодонтической коррекции. Ортодент-Инфо. 1998; 3: 45-6. 